\title{
The Future of Comparative Politics is its Past
}

\author{
Dwayne Woods ${ }^{1}$
}

Received: 21 March 2016/Accepted: 15 June 2016/Published online: 4 July 2016

(C) Fudan University and Springer Science+Business Media Singapore 2016

\begin{abstract}
Schmitter advocates that the future of comparative politics should be about addressing context, complexity, aggregate dynamics, limits to simplified cross-national generalizations, non-reductive assumptions about individual rationality, and an analytical method that is pragmatic and realistic in its assumptions. In this short essay, I argue that most of what Schmitter calls for as the future of comparative politics is already present. Schmitter has reengaged in a debate and discussion that goes back to the origins of comparative politics, and that is how to balance its theoretical inclination for broad cross-national generalization with its area (case) study empirical basis. In this respect, the future of comparative politics is its past!
\end{abstract}

Keywords Comparative method · Area (case) studies $\cdot$ Neo-positivism $\cdot$ Logic Comparative analysis

This issue of the Chinese Political Science Review (CPSR) is organized around a discussion and debate animated by Professor Philippe Schmitter's essay-The Future of Comparative Politics. Professor Schmitter's essay is important for this recently established academic journal for two reasons. First, the objective of CPSR is to publish articles that are not limited to China. The objective of the journal is to draw on all of the sub-fields of political science, including comparative studies. In this respect, its name should be viewed in the same way as the American Political Science Review (APSR). Second, the emergence of China as a global power entails situating China and its phenomenal socio-economic transformation within a theoretical and conceptual comparative framework. Much of our knowledge about China is derived from area (case) studies, but our interest in China is linked to larger

Dwayne Woods dwoods2@purdue.edu

1 Department of Political Science, Purdue University, West Lafayette, IN 47907, USA 
theoretical issues relating to democratization, authoritarian regimes, and modernization. Schmitter's reflections on The Future of Comparative Politics revisits topics that have been covered in the past and outlines the direction that he believes comparative politics should be moving towards in the future. Whatever that direction will be, China figures prominently in it since its emergence as a global force brings back to the forefront two core identities of comparative politics. On the one hand, the rise of China reinforces the centrality of area (case) studies. China's continental size and diversity makes it a locus for comparative analyses. On the other hand, there is an imperative to understand China within theoretical and conceptual frameworks that are not bounded by its historical uniqueness or spatial location. In cross-national comparative studies, China is a data point like any other.

There are many dimensions to any reflection on The Future of Comparative Politics and how to situate China within it (Jing and Wang 2009; Zhong 2009; O'Brien 2011; He 2011; Tsai 2013). Rather than trying to engage with all of them, this essay focuses on just two. First, there is the issue of what type of sub-field is comparative politics within the broader field of political science. Second, there is the issue of whether comparative politics has its own logic (Habermas 1998; Parsons 2007). These two issues have been at the core of comparative politics since its inception. I postulate, therefore, that in relationship to these two dimensions, comparative politics' future has always been about its past, since its past entailed how to situate one of its core identities-area (case) studies-into its other core identity - making generalizations that go beyond any particular area or, in the more extreme, time-frame. In this respect, the scope of comparative politics-area (case) studies and generalizations - is captured in the "widely accepted definition of the sub-field as the study of politics and political power around the world" (Munck and Snyder 2007: 8). As recognized by Aristotle long ago, politics and power are universal but how they are institutionalized, measured, and exercised is heavily context dependent.

Comparativists have sharply divergent views about the scope, objectives, and the logic(s) of comparative politics (Tilly 1984; Munck and Snyder 2007; Munck 2007). For simplicity and provocative purposes, I divide these divergent views into two radial families. On the one side, there are those who advocate a neo-positivist perspective on comparative politics in which the scope and primary objective of the subfield is to engage in developing robust, hypothetico-deductive, propositional statement models that can be "tested," and assessed, cross-nationally in terms of their statistical significance and implicit causal effects (Lane 1996; Steinmetz 2005; Clarke and Primo 2012; Yom 2015). On the other side, there are those who argue that comparative politics is primarily a sub-field concerned with understanding power and political processes within and across areas (cases), especially since the empirics of the sub-field arise from its area foci. Comparative Politics emerged as a subfield in political science simultaneously as field of area (case) studies with the objective of engaging in cross-national comparisons and generalizations. Thus, the tension and perennial debate between the two camps is inescapable and without any ultimate solution because of the nature (ontology) of the subfield itself (Lane 2016). Although the debate and tension are probably inevitable, I think nonetheless that Philippe Schmitter's essay formulates some pragmatics, i.e., practical analytical 
ways, of engaging as comparativists that should lessen the tension between the two familial camps that underpin comparative politics as a sub-field in political science.

\section{Area Studies and Comparative Politics}

Let me start with how to think about comparative politics as a subfield within political science (Kling 1964). Comparative Politics emerged as an identifiable subfield in the immediate period following the Second World War. In many ways, the formal-legal approach that predominated in cross-national constitutional studies served as an antecedent to area studies in comparative politics. As Zhong (2009: 336-337) puts it: "arguably, comparative politics was also born around the same time when Woodrow Wilson, the political scientist, began to promote comparative and historical study of political institutions in the United States and other countries." However, as a subfield, it was born of necessity. And that necessity was for the United States - a global power-to know something about other places (Kahin, Pauker, Pye 1955). Interestingly, the initial other place that defined the research agenda for comparativists was Europe. A concerted effort was undertaken to explain the rise of fascism and the failure of democratization to take hold across many European nations between the World Wars. Lipset (1959), although a sociologist, provided a seminal study on democratization that emerged within this context. Because of geographical proximity and Cold War imperatives, Latin America quickly emerged as a major area studies focus for many comparativists. Philippe Schmitter's work on Brazil is a good illustration of this development. Asia and Africa soon followed. As a subfield, comparative politics brought the "world's regions and peoples" into the purview of American political science. American political science provided the framework in the context of what is referred to as the behavioral revolution.

Munck (2007: 43) describes the behavioral revolution and its connection to comparative politics,

Behavioralism in comparative politics, as in other fields of political science, stood for two distinct ideas. One concerned the proper subject matter of comparative politics. In this regard, behavioralists reacted against a definition of the field that restricted its scope to the formal institutions of government and sought to include a range of informal procedures and behaviors-related to interest groups, political parties, mass communication, political culture, and political socialization - that were seen as key to the functioning of the political system. A second key idea was the need for a scientific approach to theory and methods. Behavioralists were opposed to what they saw as vague, rarified theory and atheoretical empirics, and argued for systematic theory and empirical testing. Thus, behavioralists sought to bring about major changes in the established practices of comparative politics.

In regards to the idea that there is a unique logic to comparative politics, the behavioral revolution engendered an effort to ground comparative studies and its area studies orientation into a "neo-positivist" mold. Thus, the broader field of 
political science initially provided the theoretical and conceptual language that was used to frame the way area studies specialists engaged with their areas. Interestingly, despite the purported emphasis of the behavioral revolution on methodology, it offered little in the way of methodology and research design. Comparativists, especially those engaged in fieldwork, had to borrow from anthropology and sociology in their efforts to apply prevailing theories to their areas of specialization (Munck 2007: 39-42).

The theorizing of the immediate post war period reflected abstract systems theory, heavily influenced by Talcott Parsons from sociology (Munck 2007: 39-42). Zhong (2009: 337) describes the thrust of this kind of abstract theorizing,

A number of studies in the 1950s and the 1960s paved the way for the birth of contemporary comparative politics. One scholar was David Easton who developed systems theory in political science. According to his systems theory, all political systems are like organic human bodies with input, output and feedback functions. The input functions of a political system consist of support and demand; the output function refers to policy formulation, and the feedback function concerns the evaluation of policies. Among the other significant contributions in Easton's systems approach to politics, this new theoretical framework de-ideologized the previous political development theories, including the totalitarian model. Easton believes that all political systems have to have the input function of support. In other words, any political system has to enjoy certain degrees of political support from within the system. Otherwise the system would not survive. The implication in systems theory is that even in authoritarian and totalitarian countries the political system and its leadership enjoys certain degrees of political support.

The abstract systems theory proved difficult for area specialist to accommodate to the realities on the ground. As Schmitter (1993) noted, “... the key fruits of the behavioral revolution in comparative politics was overly abstract and used categories that were not grounded in the realities of third world societies" (cited by Munck and Snyder 2007). There were two reactions for the lack of fit between the overly abstract theorizing and realities on the ground. On one hand, area specialists increasingly turned to inductive theorizing and conceptualizing as a way to fit their "realities on the ground" with comparative analysis. On the other hand, there was a drive to generate a neo-positivist frame specific to comparative politics (Kalleberg 1966). This latter effort gave rise to the claim that comparative politics actually had its own logic and that this logic was a method-the comparative method (Lijphart 1971; Collier 1991). Lijphart (1971) defined the comparative method as ...one of the basic methods-the others being the experimental, statistical, and case study methods - of establishing general empirical propositions and ... as a method for discovering empirical relationships among variables (Meckstroth 1975: 132; Faure 1994). 


\section{The Neo-positivist Logic and the Future of Comparative Politics}

In their seminal book, The Logic of Comparative Social Inquiry, Przeworski and Teune (1970) attempted to establish an overarching logic to comparative politics. They essentially collapsed a theory of comparative inquiry into a method. Przeworski and Teune (1970: 75-76) argued that the comparative method was a scientific method aimed at establishing general empirical propositions and identifying empirical relationships among variables free of cultural and system level (nation-state) distortions. They claimed that this could best be achieved by adopting a modified form of J.S. Mill's comparative logic based on his method of difference that they coined the "most difference systems design." Arising from this logic and method, comparative analysis functions as follows: "(1) the factors that are common to the countries are irrelevant in determining the behavior being explained since different patterns of behavior are observed among systems sharing these factors; (2) any set of variables that differences of behavior ... can be considered as explaining these patterns of behavior." The central precondition to comparative analysis thus involved overcoming the presumed problem of too many variables and too few cases. The suggested remedy was to increase the number of cases, thus reducing the "property space of analyses." In doing so, comparative inquiry could proceed to make general theoretical statements regardless of the social system by relying on general concepts that can travel cross-nationally and by controlling for system-level influences as much as possible (Przeworski and Teune 1970: 75-76).

The cornerstone of Przeworski and Teune's (1970) logic of comparative analysis was their idea that "irrelevant systemic factors" could be logically and empirically eliminated. Strong conceptual formation grounded in robust theory would result in the logical elimination of "irrelevant systemic factors" by establishing equivalences across systems. Empirically, this would be done by focusing on individual level attributes "within systems by searching for independent explanatory variables that are measured within each system and measured in the same way across systems." At the theoretical level, it is important to specify the structural developments and transformations that are likely to give rise to similar behavioral dispositions despite cross-national system (cultural) level differences. Although they do not mention modernization theory, it lurks in the background.

Przeworski and Teune's (1970: 29-30) book became a classic in comparative politics largely for the following statement,

The basic assumption is that names of nations or social systems in general, are treated as residua of variables that influence the phenomenon being explained but have not yet been considered. Thus, such concepts as "culture," "nation," and "political system" can be treated as residua of variables, which can be incorporated into a general theory. ... The role of social science is to explain social events. Explanations consist of general sentences, or more precisely, of theories or sets of such general sentences, to particular events. ... Therefore, the role of comparative research in the process of theory building or theory 
testing consists of replacing proper names of social sciences by the relevant variables.

They articulated a comparative logic that incorporated area (case) studies with the development of "theories or sets of general sentences" into different contexts and events. The neo-positivism of their argument resides in their assertion that "explanation in comparative research is possible if and only if particular social systems observed in time and space are not viewed as finite conjunctions of constituent elements, but rather as the residua of theoretical variables." Law-like sentences could only be used "if the classes of social events are viewed as generalizable beyond any particular historical system." Thus, the logic of comparative politics was largely about situating area (case) studies within a broader theoretical framework that abstracted from context by replacing proper names of social systems by the relevant variables" (Przeworski and Teune 1970: $30)$.

Regardless of the overall neo-positivist ambitions of Przeworski and Teune's (1970) project, its only lasting influence on comparative politics has been the dropping of pronouns for variables in large $\mathrm{N}$ cross-national regression analyses. Although some of the within and system level issues that they tried to address is linked to this notion, comparative politics never came to rest on the neo-positivistic logical foundation advocated by Przeworski and Teune (Meckstroth 1975). The replacing of the proper names of social sciences by the relevant variables is the only thing from the book that is remembered; it is still widely cited and referenced despite other noteworthy innovations. For instance, Pzeworski and Teune (1970) were among the first to identify factor analysis as an important tool in establishing conceptual and measurement equivalence across cases and their "most different systems design" was a harbinger to hierarchical modeling. The importance of fixed and random effects was raised in the book and their relevance to comparative crossnational analysis addressed (Teune 1975). Suffice it to say, area (case) studies in comparative politics did not become residua of theoretical variables. Much of the empirical work done in comparative politics remains in area (case) studies, withironically - the theoretical variables often becoming the residua of area (case) studies.

\section{A Different Take on the Logic of Comparative Politics}

The neo-positivist urge did not disappear with the waning influence of Przeworski and Teune's book. The idea that comparative politics is distinct because of its logic persisted. The idea that comparative inquiry is premised on the logic of its method reemerged in a different guise in an article published in the Journal of Chinese Political Science in 1999, aptly titled the "Future of Comparative Politics." Robert Bates, sought to reclaim the comparative method as a core logic of comparative politics. Like Lijphart (1971) and Przeworski and Teune (1970), Bates claimed that the comparative method is a form of inquiry that gains its scientific status by making comparisons. Bates, however, shifts the emphasis away from theoretical statements 
and residua of theoretical variables in terms of "method of similar and differences" to another aspect of comparative inquiry, that is, its supposed ability to provide a substitute for the gold standard in science -randomized control trials. Bates (1999) argued that since we cannot conduct randomized experiments on a large scale across and even within nations, we should turn to the comparative method as a second best approach.

The comparative method presumably allows some degree of control in the selection of cases - a type of matching exercise to capture the impact of explanatory variables while controlling for the effect of others that may be of less theoretical interest. Bates (1999: 3) noted that to employ case selection as a means of causal inference, we need to make a key assumption: that the cases are, in fact, homogeneous, in the sense that "the expected value of the dependent variable will be the same for each case, when the explanatory variable takes on a particular value." Viewed in this light, the growing homogeneity of the political systems across "the globe can be seen as facilitating comparative inquiry and therefore strengthening, rather than weakening, our field." Stating further that:

Thus far I have argued that comparative politics is a field that is based upon method; that the presumed homogenization of politics, globally, and the existence of large-scale collections of data, highlight the utility of returning to large N, cross-national research; and that the sub-fields of political economy and development are best positioned to secure rapid advances from their redirection. I have also emphasized that we need to blend cross-national statistical research with in depth case studies, arguing that the two are not substitutes but rather complements, and should be pursued in tandem (Bates 1999: 9).

Bates failed to note that the supposed homogenizing effect that globalization was bringing about was strikingly similar to assumptions in the modernization model several decades earlier. Basically, globalization was bringing about systematic sameness, opening up the door, once again, for dropping proper names.

Bates' efforts to formulate a logic based on the comparative method never really gained any traction. Ironically, Przeworski (2007) highlighted in an essay titled "Is the Science of Comparative Politics Possible?, the reasons that Bates' argument that the comparative method could function as a kind of substitute for experiments is not feasible. In a nutshell, Przeworski (2007) argued that context, that is, the historical spatio-temporal context that he and Teune claimed could be bracketed with strong theoretical propositions could not be convincingly decontextualized. Endogeneity would bedevil all attempts to do so.

\section{Why the Persistence of Area Studies}

Despite recurrent efforts to ground comparative politics in a neo-positivist logic, area (case) studies persist (Bates 1997). As Muck and Snyder (2007: 14) state that “... a second round of challenges from different quarters that criticized area studies for being atheoretical and lacking methodological sophistication... most research in 
comparative politics during the past 15 years still focuses on one geographical region. Indeed, single-region studies are by far the most common type of article..." There is a simple explanation as to why proper names have persisted and have not been replaced by variables in comparative politics (Munck and Snyder 2007). Akin to the bank-robber's retort as to why he robbed banks, because that's where the money is; area studies persist because that's where the data and analytical narratives are (Szanton 2004). While comparativists have sought a theoretical and conceptual framework that allows for generalizations across regions and political systems, much of the substantive empirical work is still done by area specialists. Comparative political inquiry has never succeeded at getting rid of "irrelevant system level" factors nor identifying explanatory variables that account for withinsystem dynamics that travel across systems because these "irrelevant system level" factors have proven over and over again, borrowing from Przeworski and Teune (1970), to be more than residua. I will go so far as to say that the ontology of comparative politics is area (case) studies. Thus, field research abroad is not just a rite de passage for most comparativists, it is an indispensable component of their theorizing and empirical testing.

The real tension in comparative politics is not about overcoming area (case) studies and bounded descriptive analysis, but situating what we know from different regions with the prevailing theoretical and conceptual topics that predominate at any given moment in political science. In other words, area (case) studies are framed by a variety of theoretical and methodological logics. As Sil (2009: 27) states,

Area studies encompass many distinct forms of nomothetic and idiographic scholarship_ranging from illustrations of theoretical models and case studies to historical narratives and ethnography-each reflecting distinctive epistemological principles. Area-specific narratives can certainly support nomothetic endeavors, and interpretive understandings can certainly be constructed as causal stories.

In this respect, area specialists on China are confronted with the same issues that area specialists from other regions have been faced with, and that is how to link concept formation and theory building to their areas (Slater and Ziblatt 2013; Taylor 2016). Kelee Tsai (2013) underscores these tensions. Tsai (2013: 860) notes that

China scholars earn the respect of their disciplinary colleagues by making analytic, not just descriptive, claims. Students of Chinese politics are expected to translate their findings into concepts and paradigms derived from familiar cases of development-or more ambitiously, to generate novel theoretical insights that contribute to the broader discipline of political science. Interpreting Chinese politics through conventional categories is an exercise in showing what political science can do for China studies, while proposing new analytic terms demonstrates what the case of China can do for political science.

She adds that much of the scholarship that is produced by China specialists seeks to engage with non-specialists by relying on theoretical and conceptual frameworks 
that are not bounded to a particular region. Tsai (2013: 868) provides the following example:

A multi-authored effort at comparison is Scott Kennedy's (2011) edited volume, Beyond the Middle Kingdom: Comparative Perspectives on China's Capitalist Transformation, which includes multiple examples of how to situate China's social policies, economic performance, and state-society relations comparatively and more symmetrically (i.e., going beyond the use of nonChina shadow cases).

However, she adds that there are dangers in trying to apply theories and concepts in a cross-regional and cross-national way. For example,

With the rapid rise in social inequality, for example, it became fashionable to decry the "Latin Americanization of China" (zhongguo de lanmei hua), both within and outside of China. It is interesting to note that this trope has inspired more discussion among nonacademics than among comparativists-probably because most China specialists lack the language skills and networks to conduct research in Latin America, and Latin Americanists face similar obstacles when thinking about China. Comparisons with India have inspired more direct efforts, yet the influence of truly comparative academic products remains nascent. Partnering between the respective area specialists could ameliorate this hesitation (Tsai 2013: 868).

Regardless of the dangers, area studies specialists are compelled to be comparative for the reasons highlighted by Kevin O'Brien (2011: 537). First, there is a professional imperative,

Chinese politics experts of all stripes are designing articles for The American Political Science Review or World Politics, or seeking to gain an acceptance in Comparative Politics or Comparative Political Studies or more specialized disciplinary outlets. This makes sense at a time when reform and opening up have made China look more familiar to those who study other countries. Researchers on Chinese politics have much to say to political scientists who examine the political economy of development, the role private entrepreneurs play in political change, the effects of foreign direct investment, policy implementation, regulation, the rule of law, citizenship, legitimacy, popular support, property rights and many other topics.

Second, O’Brien (2011: 537-538) adds that

There is much low-hanging fruit to be harvested from the China case and perhaps the time has come to put Chinese exceptionalism aside permanently and to associate ourselves not with a single country but with problems than can be studied in that country. This has already happened to a large extent for most area studies within political science: why should we be holdouts?

Because of the size and diversity of China, China is, in many ways, its own case study. Analogous to the way that American political scientists have treated the United States, some in China do not see the need to situate the country within a 
broader theoretical and analytical framework (Jing and Wang 2009). Zhong (2009: 339) warned against this inclination:

Many Chinese scholars like to use the phrase of "Chinese local conditions" (国情) to describe unique Chinese political, social and cultural characteristics. However, as social scientists, we should not be content in using "local Chinese conditions" or "special Chinese cultural factors" to explain political behavior and phenomena in China. Instead, we should decompose the "special Chinese conditions" and "cultural factors" for the deeper meaning of these conditions and factors so that we can conceptualize and elevate these conditions and factors to a theoretical level. A major task for comparative political scientists is to make connections between political phenomena and behavior in different countries in an effort to develop universal political science theories. The process of developing political science theories through comparative studies of different countries and regions involves different levels of analysis. Political phenomena and behavior may appear quite different and unrelated in appearance; however, if we elevate them to a higher level, they are indeed comparable.

The inclination by area (case) study scholars to emphasize what is unique and different about their regions or cases is natural. Nonetheless, the concepts and the argumentation about what makes their area or case(s) unique are ipso facto comparative.

From Munck and Snyder's (2007: 12) empirical study of what is published in three major comparative political science journals, we have a good picture of how comparative politics has evolved over the decades. We know from this study and others that the "neo-positivist" push has come to little. Apparently, a significant amount of comparative studies are single-country studies. Most non-single countries studies focus on no more than five countries. Thus, comparative politics remains closely connected to the core identity of area studies. More importantly, "neopositivist" attempts to give the "comparative method" a unique epistemological or statistical status with regard to comparative politics has not succeeded. Munck and Snyder (2007: 12) inform us that "the overwhelming majority of theorizing in comparative politics is inductive, which highlights again that comparativists tend to work close to the empirical level." There is no "comparative method" per se and comparativists use a variety of methodological tools-both qualitative and quantitative. Thus, the "future of comparative politics" is its past.

\section{The Future of Comparative Politics Is Its Past}

Schmitter's critical reflections are part of a long tradition in comparative politics, that is, specifying the pragmatics of the subfield and the kinds of issues and problematiques that serve as the meta-basis of comparative analysis, be it single, multiple or large $\mathrm{N}$ studies. As he highlights, comparative politics has family ties to sociology, anthropology, history, political theory, and economics. Each of the family ties come, in many respects, with their own logics. A central problematic of 
comparative political analysis is how effectively it has subsumed these logics into an encompassing comparative pragmatics. Schmitter has articulated what I am defining as a none "neo-positivist" view. Similar to the neo-positivist view, Schmitter believes that comparative inquiry is about method. However, the method is an analytical one rather than a constitutive logic that can generate universal proposition and empirical falsification criteria (Lane 1996). In Schmitter's view, comparison is an analytical method-probably the best available one-for advancing valid and cumulative knowledge about politics. The analytical comparative method, however, is different from past attempts to identify a distinct epistemic logic to comparative politics. Instead it comes closer to the ontology of politics and that is the study of power by identifying and labeling general relations of power and then examining how they produce variable or invariable effects in otherwise different societies. Obviously, this entails the study of institutions, individual-level dynamics, aggregative dynamics, and complexity. Thus, an analytical method does not lead to the type of general scientific propositions and falsification principles that the neo-positivists sought.

Most of what Schmitter is advocating for is already being incorporated into the theorizing, research design, and methods of comparativitsts. The pragmatics advocated by Schmitter, in fact, undergirds the way in which most comparativists attempt to situate their area (case) studies. Area (case) studies has always been about context and levels of analysis. Now quantitative comparative studies increasingly recognize the centrality of context. Franzese (2007: 29) argued that context matters in three ways,

First, the outcomes we seek to explain, understand, or predict have multiple causes, so the values of the many potential causes in any given context affect the outcomes: multicausality. Second, the effects of each cause on outcomes depend on the values of one or more other potential cause(s) present in that context: context-conditionality. Third, the many outcomes and many putative causes in the political world that we seek to understand tend, in fact, to cause each other to some degree rather than some factors being only causes and others being only effects: endogeneity.

Thus, the discussion between cross-national generalizations and area (case) studies is no longer about multicausality, complexity, and endogeneity. There is a consensus that these elements are central to comparative politics. They are challenges to inferences in studies that focus only on a few cases or in large $\mathrm{N}$ studies (Pepinsky 2015). The same is true for complexity. The recognition that complexity is inherent to comparative politics accounts for the emergence of mixed methods (Weller and Barnes 2014). In addition to the importance of mixed methods in most research designs of comparative analysis, be they large $\mathrm{N}$ or case studies, there is growing emphasis on causal empiricism in comparative politics. Confidence in the external validity of average effects in large $\mathrm{N}$ studies has been called into question (Aronow and Samii 2016). Samii (2016: 949-950) states that "causal empiricism is an approach that is realistic about the specificity of the causal estimates that we can obtain. This is an implication of the fact that causal identification is difficult to obtain." The fact causal identification is something 
difficult to obtain forces comparative politics back to more localized context. In other words, it brings it back to area (case) studies.

\section{References}

Aronow, Peter, and Cyrus Samii. 2016. Does regression produce representative estimates of causal effects? American Journal of Political Science 60(1): 250-267.

Bates, Robert H. 1997. area studies and the discipline: a useful controversy? PS: Political Science and Politics 30(2): 166-169.

Bates, Robert. 1999. The future of comparative politics. The Journal of Chinese Politics 4: 1-12.

Clarke, Kevin A., and David M. Primo. 2012. A model discipline: political science and the logic of representation. Oxford: Oxford University Press.

Collier, David. 1991. The Comparative Method: Two Decades of Change. In Comparative Political Dynamics: Global Research Perspectives, eds. Dankwart A. Rustow and Kenneth Paul Erickson, 7-31. New York: Harper Collins.

Faure, Andrew M. 1994. Some Methodological Problems in Comparative Politics. The Journal of Theoretical Political Science 6(3): 307-322.

Habermas, J. 1998. On the logic of the social sciences. Cambridge: MIT Press.

He, Baogang. 2011. The dilemmas of China's political science in the context of the rise of China. Journal of Chinese Political Science 16: 257-277.

Jing, Yuejin, and Guoqin Wang. 2009. Western political research approaches and the development of political science methodology in China. Journal of Chinese Political Science 14(3): 299-315.

Kahin, George Mct, Guy J. Pauker, and Lucian W. Pye. 1955. Comparative politics of non-western countries. American Political Science Review 49(4): 1022-1041.

Kalleberg, Arthur L. 1966. The logic of comparison: a methodological note on the comparative study of political systems. World Politics 19(1): 69-82.

Kling, Merle. 1964. Area studies and comparative politics. The American Behavioral Scientist 8(1): 7-11.

Lane, Ruth. 1996. Positivism, scientific realism and political science. recent developments in the philosophy of science. Journal of Theoretical Politics 8(3): 361-382.

Lane, Ruth. 2016. Satori's challenge: political models from the bottom up. Comparative Political Studies 49(8): 1128-1160.

Lijphart, A. 1971. Comparative politics and the comparative method. American Political Science Review 65(3): 682-693.

Lipset, Seymour Martin. 1959. Some social requisites of democracy: economic development and political legitimacy. American Political Science Review 53(1): 69-105.

Meckstroth, Theodore W. 1975. 'Most similar systems' and 'most different systems': a study in the logic of comparative inquiry. Comparative Political Studies 8(2): 132-157.

Munck, Gerado L., and Richard Snyder. 2007. Debating the direction of comparative politics: an analysis of leading journals. Comparative Political Studies 40(1): 5-31.

Munck, Gerardo L. 2007. The past and present of comparative politics. In Passion, Craft, and Method in Comparative Politics, ed. G.L. Munck, and Richard Snyder. Baltimore, MD: Johns Hopkins University Press.

O'Brien, Kevin. 2011. Studying Chinese politics in the age of specialization. Journal of Contemporary China 20(71): 535-541.

Parsons, Craig. 2007. How to map arguments in political science. Oxford: Oxford University Press.

Pepinsky, Tom. 2015. Note \& Comments. Disciplining southeast Asian studies. Sojourn: Journal of Social Issues in Southeast Asia 30(1): 215-226.

Przeworski, A., and Henry Teune. 1970. The logic of comparative social inquiry. New York: Wiley.

Przeworski, A. 2007. Is the Science of Comparative Politics Possible? In Oxford Handbook of Comparative Politics, ed. Carles Boix, and Susan Stokes. New York: Oxford University Press.

Robert J., Franzese.Jr. 2007. Multicausality, Context-Conditionality, and Endogeneity. In Oxford handbook of comparative politics, ed. Carles Boix, and Susan Stokes. New York: Oxford University Press.

Samii, C. 2016. Causal empiricism in quantitative research. Journal of Politics 78(3): 941-955. 
Schmitter, Phillipe C. 1993. Comparative Politics. In The oxford companion to the politics of the world, ed. J. Krieger. New York: Oxford University Press.

Sil, Rudra. 2009. Area studies, comparative politics, and the role of cross-regional small-N comparison. Qualitative \& Multi-Method Research 7(2): 26-30.

Slater, Dan, and Daniel Ziblatt. 2013. The enduring indispensability of the controlled comparison. Comparative Political Studies 46(10): 1301-1327.

Steinmetz, George (ed.). 2005. The politics of method in the human sciences: positivism and its epistemological others. Durham/London: Duke University Press.

Szanton, David L. (ed.). 2004. Politics of knowledge: area studies and the disciplines. Berkeley: University of California Press.

Taylor, John R. 2016. Between sinification and internationalization: Chinese political science in the postreform era. Chinese Political Science Review 1(2): 199-208.

Teune, Henry. 1975. Comparative research, experimental design, and the 'comparative method'. Comparative Political Studies 8(2): 195-199.

Tilly, Charles. 1984. Big structures, large processes, and huge comparisons. New York: Russell Sage.

Tsai, Kellee S. 2013. China's political economy and political science: review essay. Perspectives on Politics 11(3): 860-871.

Weller, Nicholas, and Jeb Barnes. 2014. Mixed-method research for studying causal mechanisms. Cambridge: Cambridge University Press.

Yom, Sean. 2015. From methodology to practice: inductive iteration in comparative research. Comparative Political Studies 48(5): 616-644.

Zhong, Yang. 2009. The logic of comparative politics' and the development of political science in China. The Journal of Chinese Political Science 13: 335-342.

Dwayne Woods is an associate professor of political science at Purdue University, West Lafayette, Indiana. His research interests include political economy of development, comparative data analysis, and populism. His most recent publication is "Value Orientations From the World Values Survey: How Comparable Are They Cross-Nationally? (Comparative Political Studies 2016) and "The Use, Abuse and Omertà on the 'Noise' in the Data: African Democratization, Development and Growth" (Canadian Journal of Development Studies, 2014). 